\title{
The Social Context of Early Child Second Language Acquisition (SLA)
}

\author{
Maslihatul Umami \\ English Department of Educational Faculty \\ State Islamic Studies Institute (STAIN) Salatiga \\ Jl. Tentara Pelajar No. 02 Salatiga, Central Java, Indonesia \\ umamie@gmail.com
}

\section{Abstract}

This article addresses the material on language acquisition in a social context and focuses on the gradual shift in the child's use of words, from labeling specific and often single referents to the use of words for signifying categories of objects, actions, or attributes. The aims of this study are to search and explore the information whether the social context of second language acquisition occurred and whether it gives consequences toward cognitive development of the children. It can be seen from the results of this study that the rate and breadth of this shift varies from one social context to another, and that it has differential consequences for cognitive development dependent on the social context in which it occurs. The crucial significance of actively stimulating language growth in the classroom, especially by teachers of the socially disadvantaged, is stressed.

Keywords: Social Context, Second Language Acquisition, Children

\section{Abstrak}

Artikel ini membahas tentang pemerolehan bahasa dalam konteks sosial dan berfokus pada perubahan bertahap dalam penggunaan kata-kata pada anak, mulai dari menandai acuan tertentu dan sering pula acuan tunggal hingga penggunaan kata-kata untuk menandakan kategori objek, tindakan, atau atribut. Tujuan dari penelitian ini adalah untuk mencari dan menyelidiki informasi tentang konteks sosial pemerolehan bahasa kedua yang terjadi dan apakah hal itu memberikan konsekuensi terhadap perkembangan kognitif anak. Hal ini dapat dilihat dari hasil penelitian bahwa tingkat dan luasnya pergeseran ini bervariasi dari satu konteks sosial ke konteks yang lain, dan bahwa pergeseran ini memiliki konsekuensi diferensial untuk perkembangan kognitif tergantung pada konteks sosial di mana itu terjadi. Kemudian, signifikansi krusial dari 
usaha merangsang pertumbuhan bahasa di dalam kelas secara aktif, terutama oleh guru-guru yang kurang beruntung secara sosial, perlu ditekankan.

Kata Kunci : Konteks Sosial, Akuisisi Bahasa Kedua, Anak-Anak

\section{Introduction}

Children, surrounded by a sea of words, sequentially and selectively acquires the nouns, verbs, and phrases of their language as well as the gestures, intonations and dialect of those with whom he interacts. The rate and breadth of this complex acquisition is proportional to the scope of their verbal interactions with those charged with their care.

Language is so pervasive in human behavior that the process of language acquisition is often taken for granted. A comprehensive treatment of this process is obviously beyond the scope of this paper. There are too many gaps in our current knowledge to make such an attempt feasible.

In consideration of such limitations, therefore, this paper will focus upon social conditions that affect language acquisition. More specifically, it will focus upon the gradual shift in the child's use of words, from labeling specific and often single referents to the use of words for signifying categories of objects, actions, or attributes. The hypothesis advanced here is that the rate and breadth of this shift varies from one social context to another, and that it has differential consequences for cognitive development dependent on the social context in which it occurs. This hypothesis will be examined and discussed chiefly in terms of the pertinent literature, with occasional reference to empirical studies.

The need to modify the cognitive growth patterns of young childrenparticularly of those children who live in the slum areas of our major cities-has added new impetus to the search for a clarification of the relationship between 
language and thought. It is our intention to examine aspects of word acquisition as related to conceptual development of verbal mediation.

The literature on the development of language, structured largely in terms of maturational theory and based on the congruent findings of careful investigators, specifies an approximate sequence and timetable of children's verbal development. The focus of many of these studies has been on the rate of language acquisition, the unit studied being the number of different words elicited from the young child in a standard setting. Here, the social environment is viewed either as a hampering or as enhancing medium in which the development of speech occurs, and the basic process of growth is considered neurophysiologically determined.

Although these studies have given us more facts about the increase of the child's active vocabulary, they develop within the context of modern psychological theories such as those of Hebb and Hunt (1992). Similarities in the quantitative features of overt behavior (i.e., the size of spoken vocabulary) are assumed, by normatively oriented researchers, to be behaviors functionally equivalent for groups of children differing in background. However, studies limited to word counting afford little insight into the dynamic relationship between social experience and language. While many of these investigators (Gesell \& Templin: 1997) may be aware that the content of speech is culturally determined, too often their writings have not reflected this awareness.

In contradistinction to the maturational approach to language development as exemplified by the investigators mentioned above, Osgood's model of language conceptualizes words as abbreviated motor behavior (Osgood: 1999) .While his approach permits a simplified description of the complex behavior of language, it focuses on variables which would appear to be tangential to language acquisition. More importantly, motor learning 
requires little social interaction, but language cannot be acquired in an interpersonal vacuum.

On the other hand, the theoretical writings of Bernstein (1990), and the recently translated book of Vygotsky (2000), present approaches which are useful in the study of language acquisition in a social context. In his writings, Berstein (1990) emphasized status as a major social determinant of speech patterns within social groups. More centrally related to the approach taken in this paper are hypotheses advanced by Vygotsky (1970) three decades ago. He proposed that the conditions that influence the development of speech (overt language) are also related to the development of verbal meditation (covert language). Further, he suggested that a socially determined learning condition of central importance in the acquisition of language is the availability of adults for engaging the child in dialogue (McCarthy: 1991).

Consequently, the central theme of this discussion, partially based on Vygotsky's thinking (1970), is that children develop and test their tentative notions (hypotheses) about the meanings of words and the structure of sentences chiefly through verbal interaction with more verbally mature speakers.

\section{The Acquisition of Label}

Social interaction with verbally mature individuals, which affects language acquisition, begins with the occurrence of the infant's earliest vocal responses. Some findings have illustrated the effects of social environment on vocalization in children as young as six month (Brodbeck and Irwin, 1996). The child's language development in the first two years of life is primarily in the nature of increasing comprehension of speech of those around him. By age two, a child has developed speaking vocabulary, which may range from 3 to 300 words. In the next two years, the child shifts from using words exclusively 
as labels with singles referents to the use of words, which have multiple referents (rudimentary categories).

This process of acquiring and enlarging the use of labels can be sketched in general terms. At an elementary stage of language acquisition, before first birthday, the child perceives a word as being one of a multitude of attributes of an object (shape, weight, color, and name). By the repeated association of seeing and touching the object, and hearing the name of the object, the child acquires a bond between word and referent. Usually, the source of auditory stimulation is the mother. In addition, children engage in communicative interaction with siblings, relatives, other children, teachers and neighbors. The role of more impersonal sources of communication, e.g., television and radio, has become increasingly important in children's acquisition of words. For example, simple learning is well understood by advertisers. The highly predictable association between the picture of the Coca Cola bottle and its name from the TV sound track is a fact of great utility in label acquisition of words.

Put on a more technical level, in describing language acquisition, some researchers rely on the conditioning paradigm. However, such a model presents certain difficulties in that it emphasizes a one-to-one relationship between stimulus and response. In reality, the word to be learned is usually embedded in a sentence (the verbal context) and its referent (the object that is to be paired with the word) is surrounded by a multitude of extraneous features in the environment. Learning labels requires selective attention-the inhibition of irrelevant aspects of the learning environment.

This learning of new verbal responses, particularly by young children, can be facilitated by a relative invariance in the environment. One of the major characteristics of the home, a natural setting for language acquisition, is its intrinsic variability. This is particularly true of lower-class homes that have 
been described, and transient in their inhabitants than middle-class homes. Children raised in such lower-class homes participated in the studies reported below.

In spite of the complexities and difficulties involved in the process of label acquisition, children do acquire words in the midst of the "noise" of the natural environment. Some accomplish this more readily than others do. The abundance of opportunities for hearing the names of objects while seeing and touching them is such that most two-year-old can understand and use effectively a number of labels.

\section{Receptive Labeling}

Children from different social classes vary in their knowledge of words. Some studies of social class differences have recorded systematic variations in verbal indices of children grouped according to fathers and/or education. Children from high-in-come, high-status families have been found to speak in longer sentences, more articulately, and with a more varied vocabulary than do their lower-class peers (Templin, 1997). Thus, in order to understand better the implications of such findings, it is necessary to examine qualitative as well as quantitative differences in children's verbal behavior.

One example of qualitative differences in children's verbal behavior emerged from an item analysis of the responses of young Negro children to a receptive verbal task, the Peabody Picture Vocabulary Test (PPVT) (Seidman: 1991). Briefly described, the PPVT consists of a series of increasingly difficult items, which require the child to display his comprehension of labels, when confronted with four drawings, by pointing to the correct picture-referent. The standardization group for this test consisted solely of white children residing in and around Nashville, Tennessee (Seidman: 1991) 
As part of a larger investigation, the PPVT was administered to fouryear-old, lower-class Negro children, who had been selected to participate in a pre-school enrichment program. This program involves the research and teaching staff of the Institute for Developmental Studies, New York Medical College, who are also engaged in a variety of projects involving lower-class Negro children. Currently, pre-school enrichment classes are being held in eight Manhattan elementary schools. The Peabody Picture Vocabulary Test (PPVT) protocols of approximately 40 experimental and control childrenbefore entering enrichment-was selected for this illustration (Seidman: 1991). Of the first 35 words of the test, clusters of items that the children had failed were identified. There, clusters of words were found to be particularly difficult: action words (digging, tying, pouring, building, pickling); words related to rural living (leaf, bee, bush, nest); and words whose referents may be rate in low-income homes (kangaroo, caboose, accident. Other studies, such as that by Eells (1991), have shown similar trends in that older lower-class children failed to identify words, such as "harp," the referents of which are not usually available in lower-class environments. These results raised a question of great interest to us: Why did these lower-class children have such a high percentage of failure with action words? If the environment provides abundant opportunity for the child to hear simple labels, then action words are as likely to be heard by lower-class children as by middle-class children. Perhaps the explanation lies in the learning environment. Children from low-income homes have relatively little opportunity to engage in active dialogue when learning labels. Milner (1996) has described the paucity of verbal interaction of children with adults in the low-income Negro home.

It is our contention, therefore, partially supported by Bernstein's (1998) research that the crucial difference between middle-class and lower class individuals is not in the quality of language, but in its use. The functional 
diversity in language may be a direct result of the occupational and educational experiences of the speaker. Middle-class occupations generally require and permit verbal interaction with a variety of people. The individual must continually adjust his speech in terms of rate, intonation, vocabulary, and grammatical complexity, in an attempt to provide optimal communication. In contrast to this, the verbal interaction required in lower-class occupations is of a routine, highly conventionalized nature. The middle-class individual, then, develops a more flexible to use of language than that found in persons from lower-class backgrounds. The gap between the speaker's verbal skill and the listener's potential for comprehension is greatest in adult-child verbal interactions. Here, the ability to use language flexibly is most important-it permits the adults to adjust his speech to fit the child's level of comprehension.

However, if the lower-class child has to rely upon the frequency of cooccurrence of label and referent to a greater extent than the middle-class child, then, for him, the invariance between word and referent must also be greater. Yet, the learning of verbs and gerunds by frequency of occurrence instead of by active dialogue is more difficult than is the learning of labels for specific objects. Gerunds such as "trying" were failed, not because the children were deficient in experience with the referent but rather because they had difficulty in fitting the label to the varying forms of action observed and experienced. This fitting process, which consists of selecting the specific connection between word and referent, occurs more easily when there is a variety of verbal interaction with adults. The middle-class child learns by feedback, by being heard, corrected, and modified-by gaining "operant control" over his/her social environment by using words that they hear. The child learns by interacting with and adult teacher who plays an active role in simplifying the various components of word-referent relation-ships. 
In this discussion, the acquisition of labels has been conceptualized as the result of the interaction of two major variables. One, the stability of the word-referent relationship, refers to the features of the referent and the degree of its invariance within the learning context in the natural environment. The second variable, derived from the frequency and type of verbal interaction during language acquisition, refers to the amount of corrective feedback the child receives while learning a new label, i.e., the consistency with which his speech is listened to, corrected, and modified.

Figure 1 illustrates the postulated relation of these two variables, in the acquisition of specific labels (A) and of action words (B). Words such as "Coca Cola" and "ball" have characteristics of high stability and physical constancy and they occur within relatively few learning contexts. Such words are easily learned by the mere frequency of co-occurrence of word and referent, and require little corrective feedback. Because of the relatively lower stability of the word referent relationship for words such as "key" and "teacher," a somewhat greater amount of corrective feedback is necessary for their acquisition. (Line A.)

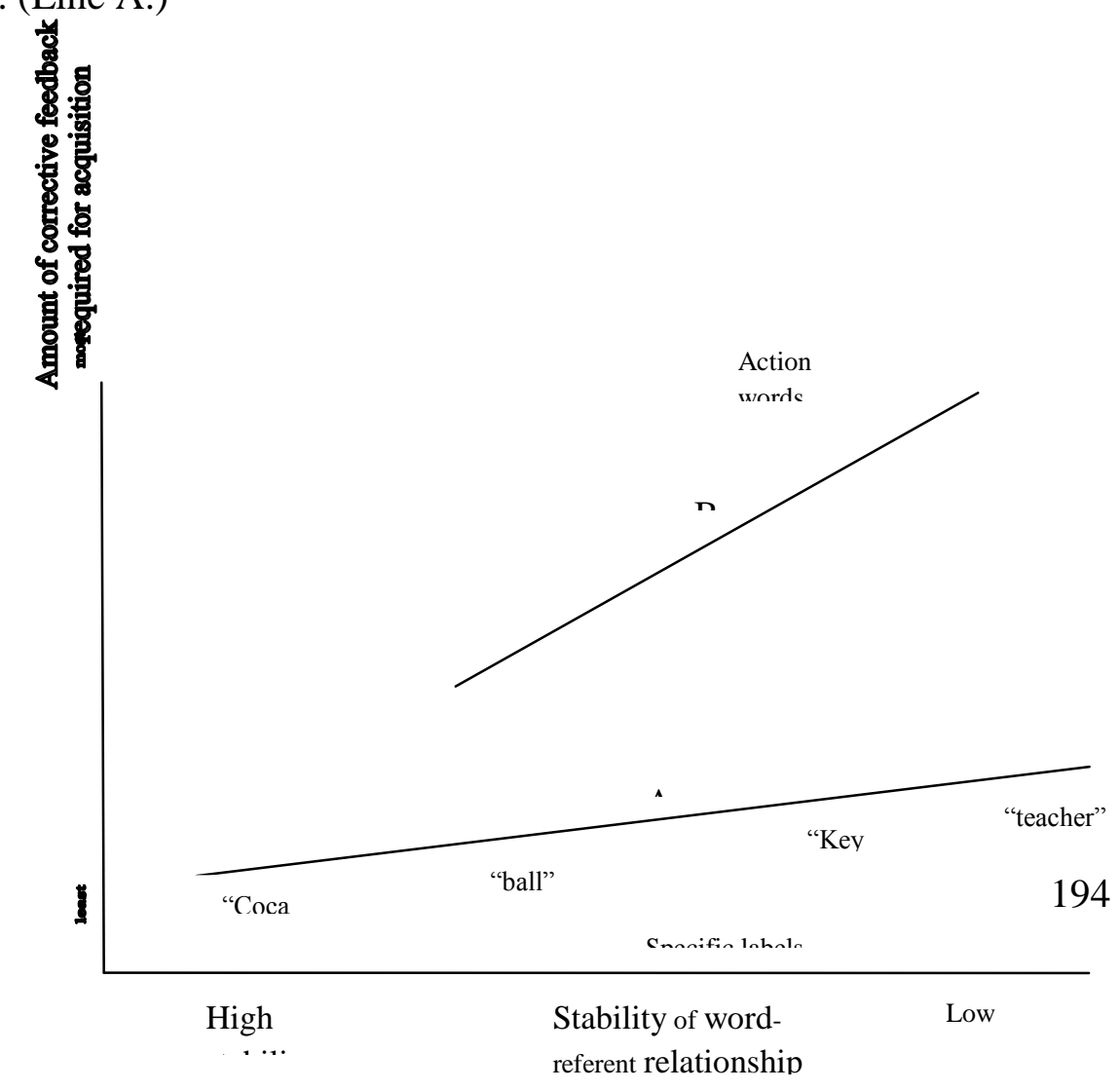


Most action words occur in contexts of moderate to high variance. As the stability of the word-referent relationship decreases, the amount of corrective feedback repaired for acquisition increases. (Line B.)

This relationship is postulated for words that are abundant in the natural environment of lower class as well as middle-class children-but not for words such as "caboose," and "accident" which may occur infrequently in the lowerclass setting. Therefore, the postulated interaction rather than experiential rarity may explain more simply the slower rate acquisition of labels and action words by lower-class children.

Briefly, our analysis indicates that the child's acquisition of words with shifting and complex referents will be impeded if required adult-child verbal interaction is insufficient or lacking.

\section{The Acquisition of Categories}

While the child acquiring new labels he also is gaining additional referents for those labels already in his repertoire. Young children, unskilled in the used of words, often reveal their understanding of the nuances of a label, i.e., the multiplicity of their referents, though non-verbal behavior. Long before the two-year-old can correctly pronounce the word "horse," he indicates that he knows several referents for the word when he hears it spoken by pointing to his rocking horse or reaching for his stuffed animal. By the quality and amount of corrective feedback he gives, the actively participating adult determines the breadth of the generalization and the precision of the discrimination the child relies upon while learning multiple referents.

The Peabody Picture Vocabulary Test data discussed earlier indicate that lower-class children, because of insufficient corrective feedback, have great difficulty in acquiring words that appear in a number of different contexts. The specific context in which a label is first acquired, one characterized by low 
"noise" or one in which these is frequent reoccurrence of label and referent, is limiting and restrictive. Generalizing a word from one setting to another requires the discovery of the irrelevant variations that accompany. As Brown (1988) has said: “.... a speech invariance is a signal to form some hypothesis [italic ours] about the corresponding invariance of referent."

This process of discovering invariance common to multiple instances of a label is fundamental for the conceptual as well as the verbal development of the young child. However, little is known about the mechanics of this process, beyond the recognition that both generalizations and discriminations have to be made by the child learning multiple meanings of words. It means by means of corrective feedback, the child learns that a "dog" is not a horse or cat or some other grossly similar object in his environment (discrimination). He also learns that "dog" is not only that white thing with black spots, but it is also that big brown thing that makes a loud noise, and that other thing with the long floppy ears (generalization).

\section{Example from As-Salaam Kindergarten, Bandungan, Semarang, Indonesia}

Some examples of the verbalizations of lower-class and middle-class of As-Salaam Kindergarten are given below. (The concept was represented by pictures of four men at work: a policeman, a doctor, a farmer, and a sailor). Lower-class first-graders

I. "because doctor nurses these other people"

II. "because the man and big Bill (policeman) like each other"

III. "because they look the same"

\section{Middle-class first-grades}

I. "because they all men"

II. "all the same, all of them are men"

III. "They are both people." 
Two hyphoteses which were formulated in the major study are relevant here. Verbally less-experienced children were expected to short the stimulus card into a larger number of piles. It was also anticipated that middle-class children (as a group, considered to be verbally more-experienced) would offer an explicit statement of a concept, e.g., "they are all animals," while the verbal rationale of lower-class children would reflect a specific aspect of communality, e.g., "they all have leggs." These hyphoteses were partially substantiated .

The examples given above illustrate the general tenor of responses given by the children. The middle-class children tended to produce category labels more often than their lower-class peers who instead were inclined to focus on non-essential attributes. We may say that those children who were successful on this task were those who had developed skills for discovering the crucial, invariant features of objects having the same name.

Based on the examples, the individual's ability to solve complex problems is related to the use of the children in making up language in verbal mediation. Jensen (1999) defines verbal mediation as “... verbal behavior which facilitates futher learning which controls behavior, and which permits the development of conceptual thinking." In some of their research, the Kendlers (2000) have found and increase with age in children's reliance on words as mediators while solving a reversal shift problem. Antecedent conditions necessary for the development of verbal mediation have not yet been explored.

In this paper, the reseracher posit, that while the children gains practice in correctly identifying objects having the same name, and while they develop their knowledge about the hierarchy of category-names, they also develop skills of used in verbal mediation. Again, we ascribe a crucial role in the 
development of verbal mediation to the availability of adults, who serve as language models, and who participate in an ongoing dialogue with the children.

Evidence currently available suggests that some children who can be described as proficient in overt language skills, also rely upon covert languageor verbal mediational processes- when approaching complex problems. Luria's studies (1991) of speech-delayed twins exemplify the parallel development of verbal skills and verbal mediation.

Children from backgrounds of educational retardation have been shown to perform poorly on verbal and conceptual tasks. Jensen (1999) taught a group of educationlly retarded adolescent to use verbal mediation in a task which required the learning of a list of paired associates. These subjects learned to construct a sentence around each pair of meaningful words. A control group of subjects from similar background, who were not isntructed in this use of verbal mediation, took five times as long to learn the deficiencies not only in overt verbal skills but also in verbal mediational behavior.

In our stress on the importance of variety in stimulation, our position is in basic agreement with other developmental theorists concerned with cognitive processes. However, we have also attempted to specify the demands on the child as he learns. The child,confronted with several disparate objects having a label in common, has to identify those critical features by invoking mediating responses. In both of these learning situations the child is actively searching for invariance among features of his environment. The tools he uses in this search have been sharpened in his verbal communication with others.

Communication and cognition, traditionally treated as separate aspects of language, are posited here as fundamentally interrelated in the early stages of language acquisition. Language is seen as functional behavior for the young child. While he uses his slowly developing communicative skills to inform those who care for him about his needs, he is also organizing his perceptual 
and social world through language. The social environment in which these function develop are highly complex. Particular importance is the amount of attention paid to the child's own attempts at early verbalizations: the opportunity made available to the child to learn by feedback, by being heard, corrected and modified-by gaining"operant control" over his social environment as he uses words that he has heard.

In our analysis, the child from a lower socio-economic background may experience a deficient amount of verbal interaction. He learns most of his language by means of receptive exposure-by hearing, rather than by the correction of his own active speech. Words acquired with little corrective feedback in a stable learning environment will be the minimum use as mediators, at a later stage of development. In contrast, the child whose language acquisition is characterized by active participation with a more verbally mature individual not only develops greater verbal proficiency-as a result of being listened to and corrected but also is more likely to rely on, and use effectively words as mediators.

Language is a socially-conditioned relationship betwen the child's internal and external worlds. Once able to use words as mediators, the child can effectively change his own social and material reality.

\section{Conclusion}

Can educational implications for pre-school programs be drawn from a theoretical statement on language acquisition? Though some of the ideas presented in this paper may be utilized by the early childhood educator, primarily, this treatment of verbal behavior is presented as a model of label acquisition. Ideas developed with in the context of a simplified and abstract treatment of language may have to undergo substantial modification in order to 
be applied in the classroom. However, some general points related to enrichment can be made, based upon the above discussion.

Certainly, the crucial importance of actively stimulating language growth in the classroom is recognized by teachers of the socially disavantaged. But the felling of urgency they bring to the task of increasing the verbal repertoire of children sometimes results in a stress on quantitative growth only. This emphasis on vocabulary expansion is not surprising in light of the maturational approach to language.

If the communicative and cognitive functions are significantly related at the beginning of language acquisition, it becomes important to discover ways for these aspects of language to be maintained interrelatedly in enrichment programs. A mechanical approach to vocabulary building will not produce the desired end of developing useful verbal skills. The teacher should utilized student's deeply personal experiences as basic content while imparting the mechanics of letters. Similary, the teacher in the enrichment classroom can discover the interests and concerns of her children by being sensitive to their products. In this case, In an enrichment program combining instruction and research, the researcher and her teacher-colleagues worked with the children. Each child was asked to re-tell a standard story in front of a tape recorder. In studying the modifications of the story made by each child, much was learned about sequential language as well as about the themes of particular interest to young children raised in low-income areas. These children also told a "made up" story, and in these fantasy products, they often related events of concern. Though some of the children spoke with poor articulation and others could not think up their "own" story, many children in this group displayed forcefulness of style and communicative strength in their descriptions.

As was the researcher purpose, this paper has stressed the acquisition of highly developed linguistic patterns as being crucial to young children. 
Because language is both a highly personal and an objectively necessary tool, however, the educator must be wary lest children learn to resent the acquisition of verbal skills. The teaching of words must be carried out with originality, flexibility, and restraint.

In becoming aware of some of the feature underlying label acquisition, the classroom teacher can create a variety of learning contexts built around experience of significance to the children. The teacher who is aware of the importance of verbal dialogue in the shift from labeling to categorizing, can direct learning not only by her own interactions, but, also, by helping children in the classroom to be effective speakers as well as active listeners.

\section{References}

Bernstein (1998). Learning Strategies in Second Language Acquisition. Cambridge: Cambridge University Press.

Brodbeck \& Erwin (1996). Sociolinguistics: an Introduction to Language and Society. NY Penguin

Brown (1988). The learning Curve: Elevating Childrens Academic and Competence, A Discovery of Speech Variations. Northvale NJ:Jason Aronson

Eells (1991), Second Language Acquisition and the Critical Period Hypothesis, Mahwah, NJ: Lawrence Erlbraum

Gesell \& Templin (1991). Interpersonal Dynamics in Second Language Education: the Visible and Invisible Classroom. Thousand Oaks: Sage

Hebb \& hunt (1992). A Time to Speak: a Psycholinguistic Inquiry into the Critical Period for Human Speech. Florence KY: Wadswort Publishing.

Jensen(1999), On Language.New York: New Press 
Kendlers (2000), Words as Mediators in Second Language Acquisition Learning, Florence,KY: Wadsworth Publishing

Lincoln, Y.S \& \& Guba,E.G(1985), Naturalistic Inquiry, Beverly Hills, CA, Sage Publications

Luria(1991), the Development of Verbal Skill and Verbal Mediation of Second Language Learner, Cambridge: Cambridge University Press

McCarthy (1991), Second Language Acquisition: an Introductory Course. Mahwah,Nj. Lawrence Elrbraum.

Milner(1996), Negro Mentality, University Park, PA: the Pennsylvinia State University

Osgood (1999). Understanding Second language Learning Difficulties: Looking Beneath the Surface. Thousand Oaks. CA: Sage

Patton, Michael Q (1980), Qualitative Evaluation Methods, London : Sage Publications

Seidman, Jerome M (1991), The Child, A Book of Readings, Montreal: Holt, Rinehart and Winston, Inc

Templin (1991), A child's Learning of two Languages. In E.M. Hatch,ed. Second Language Acquisition: A book of Readings. Rowley,Mass: Newbury House.

Taylor,S \& Bogdan, R (1998), Introduction to Qualitative Research Methods $\left(3^{\text {rd }}\right.$ Ed $)$, New York: Wiles.

Vygostky (1970) Attitudes and Motivation in Second language Learning. Rowley, M.A: Newbury House Publications. 